Chirurgia (2018) 113: 478-485

No. 4, July - August

Copyright@ Celsius

http://dx.doi.org/10.21614/chirurgia.113.4.478

\title{
Impact of Surgery and Early Postoperative Outcomes After Radical Gastrectomy for Cancer
}

\author{
Bogdan Filip ${ }^{1,2}$, Catalin Toma', Mihaela Buna-Arvinte ${ }^{1,2}$, Dragos Viorel Scripcariu ${ }^{1,2}$, Viorel Scripcariu ${ }^{1,2}$ \\ ${ }^{11} 1$ st Surgical Unit, Regional Institute of Oncology lasi \\ 2Department of Surgery, University of Medicine and Pharmacy "Gr. T. Popa” lasi
}

Corresponding author:

Filip Bogdan MD, PhD

1st Oncological Surgical Unit Regional Institute of Oncology

General Henry Mathias Berthelot 2-4

lasi, Romania

E-mail: bfilip79@yahoo.com

\section{Rezumat \\ Evaluarea rezultatelor postoperatorii imediate după tratamentul radical al cancerului gastic}

Introducere: Tratamentul chirurgical ramâne cea mai importanta parte a tratamentului multimodal al cancerului gastric. Datorită consecințelor nefaste ale actului chirurgical se poate întarzia inițierea tratamentului adjuvant, fapt care are consecințe directe asupra prognosticului oncologic al afecțiunii.

Metode: A fost efectuat un studiu retrospectiv ce a inclus toți pacienții diagnosticați cu cancer gastric în care s-a efectuat tratament chirurgical cu viză curativă pe o durată de 5 ani într-un singur centru. Caracteristicile clinice ale pacienților, tumorii şi intervenției chirurgicale au fost utilizate pentru a analiza care factori predispun la un tip de complicație.

Rezultate: Au fost analizați 189 de pacienți operați pentru cancer gastric, $100(52.9 \%)$ de gastrectomii totale şi $89(47.1 \%)$ de gastrectomii subtotale, fără a fi o diferență semnificativă privind incidența complicațiilor severe. Au fost 25 de cazuri (13.2\%) de fistule de bont duodenal şi 15 cazuri (15\%) de fistule de anastomoză esojejunală. Analiza multivariată a arătat că valorile albuminemiei (OR 1.9, $\mathrm{p}=0.035$ ), hipertensiunea (OR 4.22, $\mathrm{p}=0.0311$ ) şi efectuarea splenectomiei (OR 3.91, $\mathrm{p}=0.048$ ) au fost factori independenți pentru dezvoltarea complicatiilor severe; valorile albuminei (OR 1.91, $\mathrm{p}=0.0405$ ), hipertensiunea (OR 3.54, $\mathrm{p}=0.0444)$, tratamentul neoadjuvant (OR 3.97, $\mathrm{p}=0.01657$ ) şi splenectomia (OR $1.66 \mathrm{p}=0.05)$ au fost factori independenți pentru complicatiile medicale. Vârsta (OR $1.71, \mathrm{p}=0.044)$, hipertensiunea (OR 2.22, $\mathrm{p}=0.045)$ şi valorile albuminei (OR 1.92, $\mathrm{p}=0.041$ ) au fost factori independenți pentru complicațiile de tip chirurgical. 
Concluzii: Complicațiile severe după gastrectomia pentru cancer ramân cel mai important factor care împiedică sau întârzie inițierea tratamentului multimodal. Comorbiditațile la momentul intervenției, statusul nutritional şi extensia actului chirurgical sunt factori cheie care pot influența apariția şi gravitatea acestor complicații.

Cuvinte cheie: cancer gastric, gastrectomie, complicații, factori de risc

\begin{abstract}
Background: Surgery remains one of the most important part of the multimodal treatment of patients diagnosed with gastric cancer. Due to the fact that the consequences in terms of postoperative morbidity can delay the onset of postoperative chemotherapy or even can make the patient unfitted for adjuvant treatment, a thorough clinical evaluation of patient prior to surgery is mandatory.

Methods: We performed a retrospective study, which included all the patients diagnosed with gastric cancer in which radical surgery was performed during a 5-year period in a single center. All the patients', tumour and surgery characteristics were used for a risk analysis for the occurrence of overall, medical and surgical complications.

Results: There were 189 patients in whom radical surgery was performed, 100 (52.9\%) total gastrectomies and $89(47.1 \%)$ subtotal gastrectomies, without difference in term of postoperative morbidity. There were 25 (13.2\%) cases of duodenal stump fistula, $15(15 \%)$ cases of esojejunal fistula. On multivariate analysis albumin levels (OR 1.9, $\mathrm{p}=0.035)$, hypertension (OR 4.22, $\mathrm{p}=0.0311)$ and splenectomy (OR 3.91, $\mathrm{p}=0.048$ ) were independent factors for overall complications, albumin levels (OR 1.91, $\mathrm{p}=0.0405$ ), hypertension (OR 3.54, $\mathrm{p}=0.0444$ ), neoadjuvant treatment (OR 3.97, $\mathrm{p}=0.01657$ ) and splenectomy (Or $1.66 \mathrm{p}=0.05$ ) for medical complications; age (OR 1.71, $\mathrm{p}=0.044)$, hypertension (OR 2.22, $\mathrm{p}=0.045)$ and albumin levels (OR 1.92, $\mathrm{p}=0.041)$ for surgical type complications.

Conclusions: Postoperative morbidity after gastrectomy remains one of the most important factors that can impair the effectuation of a multimodal treatment protocol. Comorbidity factors, nutritional status and surgical technique are the key factors that can influence the amount and the consequence of a surgical complication.
\end{abstract}

Key words: gastric cancer, gastrectomy, morbidity, risk factors

\section{Background}

Despite the fact that we are the witnesses of an actual shift in the incidence of gastro-intestinal tumours, gastric cancer remains one of the most frequent cause of cancer related death in the world (1). Most of the newly diagnosed patients present advanced stages and in those cases a multimodal treatment, which includes a combination of chemotherapy and surgery, is often used. In patients where a perioperative chemotherapy regimen in used, only in 48 to $67 \%$ of cases postoperative chemotherapy is used $(2,3)$, one of the causes is the occurrence of surgical complications. The extent of surgi- cal resection has been a matter of debate between the surgeons in the Western and the Eastern world, the Eastern experience favors for an extended lymphadenectomy with lower morbidity and mortality rates. The Western experience in less optimistic, the proportion of surgeons that can safely perform a D2 lymphadenectomy is lower $(4,5)$ but more frequent there are high volume centers in where an extended resection can safely be performed (6). Total gastrectomy represents the standard technique for tumours in the upper third or body of the stomach, for distal tumours a subtotal gastrectomy can safely be performed. The postoperative adverse events remains 
poorly described due to the fact that there is no standardization of the definition or of the severity of a specific complication, published results of various studies report morbidity rates between $9 \%$ to $48 \%$ and mortality $1.1 \%$ to $10.8 \%(7,8)$. The risk factors for postoperative complications include age, high body mass index, an impaired nutritional status, advanced stage and a extensive lymphadenectomy $(9,10)$. Once the life expectancy has increased, the proportion of elderly patients diagnosed with gastric cancer has increased, and this subgroup of patients presents more comorbidity such as high blood pressure, diabetes, cardiovascular diseases, chronic renal failure and pulmonary disorders. Studies showed that patients with multiple comorbidities had a higher incidence of postoperative complications following gastrectomy (11). The combination of malnutrition, severe comorbidities and the impact of surgery can lead to the occurrence of a severe postoperative complication that will make the patient unable to receive postoperative adjuvant treatment and thus this can affect the oncological prognostic of the patient.

The aim of this study is to evaluate the postoperative morbidity after radical gastrectomy for cancer in a high volume center using a dedicated database and a standardized classification of adverse postoperative events.

\section{Materials and Methods}

We performed a retrospective study conducted on a prospective collected database that included all the patients that were admitted in the $1^{\text {st }}$ Surgical Unit of the Regional Institute of Oncology Iasi between May 2012 and June 2017. Only patients diagnosed with gastric cancer in which surgery was performed were included in the analysis. All the patients were positively diagnosed with gastric cancer using endoscopic biopsy; preoperative staging included: abdominal echography, thoracic and abdominal tomography and in selected cases diagnostic laparoscopy. Patients considered to have advanced tumours (large T3 or T4 tumours) on preoperative staging were submitted to a neoadjuvant treatment protocol (3 cycles of chemotherapy followed by restaging and in selected cases radical surgery). Surgery consisted in total and subtotal gastrectomy, based on the localization of the tumour (for distal tumours in which a negative resection margin was safely obtained it was preferred a subtotal gastrectomy. In all the patients radical lymphadenectomy was performed, according to the recommendation of the Japanese gastric Cancer Association and included for total gastrectomy (D2 dissection: groups 1-7 and 8a, 9p, 11p, 11d, 12a) and for subtotal gastrectomy (D2 dissection: groups 1, $3,4,5,6,7$ and $8 \mathrm{a}, 9,11 \mathrm{p}$ and $12 \mathrm{a})$. Splenectomy was routinely performed in cases of tumours involving the greater curvature, in patients with enlarged lymphnodes at the level of splenic hilum a resection of the tail of the pancreas was performed. The reconstruction method in all cases was a Roux en Y jejunal eso or gastroenterostomy. For patients with total gastrectomy a routine jejunostomy was performed.

Clinical characteristic analyzed were: age, sex, type of the disease, disease stage and tumour localization. Comorbidity factors included: diabetes mellitus, cardiac (including hypertension), chronic renal failure, chronic obstructive pulmonary disease, liver cirrhosis, preoperative serum albumin levels, hemoglobin and lymphocytes count. Surgical variables included were: type of surgery and splenectomy.

We included in the analysis any complication or death, which occurred within 30 days after surgery; postoperative complications were graded according to the Dindo-Clavien classification (12) (we included only the grade II and above complications, grade I which were considered any deviation from the normal postoperative course without the need of any pharmacological treatment were excluded).

\section{Statistical Analysis}

The quantitative variables were done using mean and standard deviation, the categorical variables by way of percentages. Categorical variables were compared using Fischer's exact 
test and continuous data using MannWhitney $U$ test. A p value less than 0.05 was considered significant. Statistical analysis was performed using MedCalc v9.2.0.1. We compared the characteristics of patients based on the occurrence of a postoperative complication, medical or surgical. A univariate and multivariate logistic regression was performed in order to identify independent predictors for complications. This statistic method was performed for overall, medical and surgical complications.

\section{Results}

During our study period there were 310 patients diagnosed with gastric cancer admitted in our unit. Of those, radical surgery was performed in 189 (60.96\%) patients, in the rest of the cases surgery consisted in either a palliative procedure (gastroenterostomy 46 cases, jejunostomy 63 cases) or a diagnostic laparoscopy in 12 cases. Patient's characteristics are described in Table 1. The median age of the patients was $65(63.69-68)$ years, with a slightly increased number of male patients (107 $(56.6 \%)$ vs. $82(43.4 \%))$. Among the 108 patients with preoperative comorbidities, 42 $(38,88 \%)$ had one comorbidity, 31 (28,70\%) had two comorbidities, $22(20.37 \%)$ had three comorbidities and $13(12.03 \%)$ had four or more comorbidities. The most frequent were the cardiovascular comorbidities in $93(49,2 \%)$ patients: hypertension $66(34.92 \%)$ patients and atrial fibrillation $32(16.93 \%)$ patients.

The tumour localization was more frequent
Table 1. Clinical and pathological characteristics on all patients

\begin{tabular}{lc}
\hline & $\mathbf{N}(\%)$ \\
\hline Age (median) & $65(63.69-68)$ \\
\hline Sex & $107(56.6)$ \\
Male & $82(43.4)$ \\
Female & $25(13.2)$ \\
\hline Diabetic & $93(49.2)$ \\
\hline Cardiac comorbidities & $24(12.7)$ \\
\hline Pulmonary commorbidities & $26(13.7)$ \\
\hline Prior chemotherapy & $10.77(10.41-11.13)$ \\
\hline Hb & $9.06(2.94-15.19)$ \\
\hdashline CEA & $10(7.39-14.01)$ \\
\hline Ca 19-9 & $26(13.7)$ \\
\hline Tumour location & $85(44.7)$ \\
Proximal & $79(41.6)$ \\
Medium & $61(32.1)$ \\
Distal & $100(52.9)$ \\
\hline Diffuse type & $89(47.1)$ \\
\hline Total gastrectomy & $68(68)$ \\
\hline Subtotal gastrectomy & \\
\hline Splenectomy &
\end{tabular}

in the body $(44.7 \%)$ and in the distal stomach $(41.6 \%)$ and the diffuse type was encountered in 61 patients $(32.1 \%)$. Surgery consisted in total gastrectomy in 100 cases and subtotal gastrectomy in 89 cases. Of those 100 patients with total gastrectomy, splenectomy was performed in 68 patients. Cardiopulmonary complications were encountered in $42(22.22 \%)$ patients; the most frequent were cardiac complications. Overall surgical complications developed in $62(32.8 \%)$ patients, as are showed in Table 2. The most frequent complications was duodenal stump fistula in $25(13.2 \%)$ cases, in all cases a conservative treatment

Table 2. Postoperative morbidity compared with the type of resection

\begin{tabular}{lcccc}
\hline & $\begin{array}{c}\text { Overall } \\
(\mathbf{N = 1 0 0})\end{array}$ & $\begin{array}{c}\text { Total gastrectomy } \\
\mathbf{( N = 8 9 )}\end{array}$ & Subtotal gastrectom & P value \\
\hline $\begin{array}{l}\text { Non-surgical complications } \\
\text { Cardiac }\end{array}$ & $23(12.2)$ & $12(12.2)$ & $11(12.35)$ & 0.88 \\
$\quad$ Pulmonary & $19(10)$ & $13(10.1)$ & $6(6.74)$ & 0.22 \\
\hline $\begin{array}{l}\text { Surgical complications } \\
\text { Duodenal stump fistula }\end{array}$ & $25(13.2)$ & $13(13)$ & $12(13.48)$ & 0.84 \\
$\quad$ Esophagogastrostomy fistula & $15(15)$ & $15(15)$ & - & - \\
Hemorrhage & $16(8.4)$ & $6(8.5)$ & $10(11.23)$ & 0.29 \\
Septic & $13(6.8)$ & $8(8)$ & $5(8.98)$ & 0.57 \\
\hline
\end{tabular}


protocol was applied with a time to closure between 4 and 31 days. None of the patients with subtotal gastrectomy developed a gastrojejunostomy fistula; in patients with total gastrectomy anastomotic fistula appeared in $15(15 \%)$ cases, in all cases we used a conservative treatment protocol. There were no differences between the rates of medical and surgical complications between the patients with total and subtotal gastrectomy (Table 2). Postoperative mortality was $2.64 \%$ (5 cases), the causes of death were cardio-pulmonary complications in 2 cases, liver failure due to cirrhosis in 2 cases and sepsis in 1 case.

We evaluated the relationship between the occurrence of postoperative complications and the clinic-pathological factors (Table 3). Among the factors studied, the preoperative levels of CA 19-9 $(p=0.0478)$, serum albumin $(p=0.045)$, the presence of hypertension $(p=0.04)$ and the number of comorbidities $(\mathrm{p}=0.024)$ were different between the patients with an uneventful postoperative course and the patients that developed a complication. Next, we tried to evaluate which preoperative comorbidities or clinico-pathological factor was significantly related to the occurrence of postoperative complication, and we performed this analysis for overall complications, cardiopulmonary and surgical complications. We found that albumin $(\mathrm{p}=0.035)$, hypertension $(p=0.0311)$ and splenectomy were significantly associated with overall complications; albumin $(p=0.0405)$, hypertension $(p=0.0444)$, neoadjuvant chemotherapy $(\mathrm{p}=0.0165)$ and splenectomy $(p=0.0506)$ were correlated with the occurrence of a cardio-pulmonary complication. The development of a surgical complication on univariate and multivariate analysis only age $(\mathrm{p}=0.0448)$, hypertension $(\mathrm{p}=0.0458)$ and albumin levels $(\mathrm{p}=0.0417)$ were significantly associated (Table 4).

Table 3. Correlation between clinic-pathological factors and the occurrence of postoperative complications

\begin{tabular}{|c|c|c|c|}
\hline & $\begin{array}{l}\text { Patients with complications } \\
\qquad(\mathrm{N}=67)\end{array}$ & $\begin{array}{l}\text { Patients without complications } \\
\qquad(\mathrm{N}=122)\end{array}$ & $P$ value \\
\hline Age (median) & $67(63-70.04)$ & $65(62-68)$ & 0.104 \\
\hline Sex & & & 0.159 \\
\hline Male & $60(31.7)$ & $67(35.4)$ & \\
\hline Female & $22(11.6)$ & $40(21.1)$ & \\
\hline $\mathrm{Hb} 11.45$ (10.19-12.3) & $10.8(10.36-11.33)$ & 0.28 & \\
\hline Lymphocites & $1400(1300-1553)$ & $1460(1310-1761)$ & 0.92 \\
\hline CEA & $2.57(1.91-4.09)$ & $2.45(1.42-2.71)$ & 0.32 \\
\hline CA 19-9 & $14.8(7.36-21.23)$ & $8.51(6.36-12.27)$ & 0.0478 \\
\hline Albumine & $40.1(39-41)$ & $37(35.2-39.9)$ & 0.045 \\
\hline Diabetes & 4 & 21 & 0.06 \\
\hline Hipertension & 28 & 48 & 0.04 \\
\hline Neoadjuvant chemotherapy & 12 & 14 & 0.12 \\
\hline Tumour localization & & & 0.072 \\
\hline Upper third & 13 & 13 & \\
\hline Body & 27 & 58 & \\
\hline Distal stomach & 22 & 57 & \\
\hline Number of comorbidities & & & 0.024 \\
\hline 0 & 27 & 54 & \\
\hline 1 & 19 & 22 & \\
\hline 2 & 20 & 11 & \\
\hline 3 & 15 & 7 & \\
\hline 4 or more & 9 & 4 & \\
\hline NO & 20 & 28 & 0.11 \\
\hline $\mathrm{N} 1-3$ & 100 & 41 & \\
\hline
\end{tabular}


Table 4. Multivariate analysis of postoperative morbidity

\begin{tabular}{|c|c|c|c|c|c|c|}
\hline \multirow[t]{2}{*}{ Variable } & \multicolumn{2}{|c|}{ Overall complication } & \multicolumn{2}{|c|}{ Medical complication } & \multicolumn{2}{|c|}{ Surgical complication } \\
\hline & OR & $P$ value & OR & $P$ value & OR & $P$ value \\
\hline Age & - & - & - & - & 1.7181 .0016 to 3.1470 & 0.0448 \\
\hline Albumine & 1.90770 .8293 to 3.9935 & 0.035 & 1.91183 .8348 to 0.9960 & 0.0405 & 1.92880 .8547 to 4.0093 & 0.0417 \\
\hline Hypertension & 4.27761 .1412 to 16.0345 & 0.0311 & 3.54160 .7368 to 17.0233 & 0.0444 & $2.2231(0.8456-5.3245)$ & 0.0458 \\
\hline Neoadjuvant chemotherapy & - & - & 3.97040 .5650 to 27.8991 & 0.01657 & - & - \\
\hline Splenectomy & 3.91080 .7768 to 19.6898 & 0.0482 & 1.66820 .3557 to 7.8240 & 0.05064 & - & - \\
\hline
\end{tabular}

\section{Discussion}

One of the most important factors that interfere with the accurate reporting of postoperative adverse events is the lack of standardization of complications definition and grading. In our institution we maintain a prospective database, which includes a standardized categorization of patient's comorbidities, of surgical characteristics and of the postoperative course of the patient. All of our cases before being entered in the database are reviewed by a dedicated surgeon for a clearly identification and accurate grading of a postoperative complication.

The presence of preoperative comorbidity can be associated with the occurrence of a postoperative complication, especially in an oncologic patient. For gastric cancer patients the combination of old age and comorbidity are the most important risk factors for complications $(13,14)$. The number of comorbidities in our study was associated with the occurrence of a complication, patients with two or more comorbidities will develop a more severe complication, result that was similar with those published in the literature in a study of 120 patients the incidence of a postoperative complication was $45.8 \%$ in patients with multiple comorbidities and $23.9 \%$ for patients without or with one comorbidity (11). The overall disease burden for a cancer patient is multifactorial, for example patients with a severe dysfunction of one organ tend to have multiple disorders of different organs (patients with chronic renal failure can develop secondary hypertension or diabetic patients which develop a nephropathy or coronary disease). Cardiopulmonary diseases (especially hypertension) and impaired liver function have been reported to be risk factors for postoperative complications after gastrectomy $(11,15,16)$. In our study hypertension was an overall risk factor for the occurrence of a complication, with a more predictive value for medical complications $(\mathrm{OR}=3.54)$ than for surgical complications $(\mathrm{OR}=2.22)$. The occurrence of a surgical complication after gastrectomy, especially duodenal stump fistula is directly correlated with the cardiovascular burden of the patient and the absence of a manual reinforcement over duodenal stump (17). In our series a stapling device was used for duodenal stump closure and in all cases a manual reinforcement was used using resorbable material. An impaired liver function, mainly due to cirrhosis proved to be an independent risk factor, and the development of a complication is strongly correlated with the severity of the disease (for chronic hepatitis OR=2.4, liver cirrhosis Child A OR= 8.4 and for liver cirrhosis Child B OR=9.38) (18). In our study we did not found that the liver cirrhosis to be a statistically significant factor for the occurrence of a complication, but this condition was present in 4 out of XXX cases of deceased patients after gastrectomy.

Moreover, nutritional status and especially low preoperative serum albumin levels represents the utmost important factor that seems to correlate with a higher risk of fistula after radical gastrectomy. Malnutrition in gastric cancer patients can be caused by anorexia, mechanical intake difficulties and the toxicity of chemotherapy and it can be aggravated in situations with high catabolism after surgical resection. The most common clinical manifes- 
tation is weight loss, sarcopenia, weakness, anemia and edema (19). One study revealed that patients with over $10 \%$ weight loss had a higher rate of morbidity and mortality (20) and that it can independently predict the occurrence of a complication $(\mathrm{OR}=3.1)$. The results of a multi-centric study showed that albumin levels $<30 \mathrm{mg} / \mathrm{dl}$ were associated with a higher risk of surgical site infection (21). In our series lower levels of albumin were predictors of both medical and surgical complications. We found that there were no differences regarding the lymphocytes count, previous reports stated that lower lymphocyte count $(<1500 / \mathrm{mL})$ could increase the risk of duodenal stump fistula (22). Especially in patients where gastrectomy was performed, weight loss remains a common problem after surgery. Patients after gastrectomy have a lower calorie intake during the first 6 months after surgery(23) ; during this period the patients will undergo a protocol of neoadjuvant treatment that will impair the nutritional status. Early identification of a malnourished patient prior to gastrectomy guaranties the success of surgery; all patients should benefit from a nutritional support unit during multimodal oncological treatment. The ideal treatment plan is to administer to the patient immunonutrition for 5 to 7 days prior to surgery and artificial nutrition for at least 7 days after surgery. In our clinic we begin enteral feeding in patients with total gastrectomy in the evening after gastrectomy using a jejunostomy inserted during surgery for at least 7 days or until oral intake is permitted.

Based on the results of this study we found that there are no differences in term of morbidity between patients with total and subtotal gastrectomy. A recent result of a metaanalysis that included 10 retrospective studies and one randomized study showed no significant difference of postoperative mortality, intraoperative blood loss and length of hospital stay (24), with similar rates of leakage, postoperative bleeding, anastomotic stricture and wound infection. The addiction of splenectomy in patients with total gastrectomy in our study slightly increased the risk of surgical complica- tions and this can be related with the addition of a pancreatic tail resection. This result is similar with those of a recent randomized multi-centric study that included 505 patients which showed that splenectomy was associated with higher morbidity and larger blood loss (25). Based on actual recommendations for advanced gastric tumours a perioperative chemotherapy regimen can be used, the aim of this combined approach is to add the advantages of neoadjuvant chemotherapy in reducing tumour size and facilitating radical surgery with the advantages of postoperative chemotherapy. In our study the neoadjuvant chemotherapy did not increased the surgical complications, but it can be an independent factor for the development of cardiovascular complication. The result of our study can be biased due to the small number of patients receiving perioperative chemotherapy.

There are several limitations of this study. Due to the fact that there is no standard method to evaluate the severity of comorbidities this study did not evaluate the effect of the severity of an individual comorbidity. One other major drawback is the relatively small number of patients that received preoperative chemotherapy. For the last 2 years every patient diagnosed with an advanced gastric tumour is referred, based on the recommendations of multidisciplinary team meeting to a neoadjuvant chemotherapy protocol. The effect of perioperative chemotherapy on the postoperative course of the patient will be the subject of a future study.

\section{Conclusions}

Severe morbidity and mortality can still be expected after radical gastrectomy. The subset of patients at high risk for development of a complication can be identified based of patient's individual comorbidity burden and on surgical variables. The surgical variables are represented by the radical gastrectomy with a possible need for an en-bloc resection and an extended lymphadenectomy. The standardization of the surgical technique and the centralization of cases in high-volume insti- 
tutions are the key elements for offering the safest outcomes for the patient. A thoroughly preoperative evaluation of the medical condition of the patient and of the nutritional status is necessary in order to identify the subset of patients in which a preoperative intervention in order to correct any physiological disorder. Patients with severe medical comorbidities should be adequately counseled regarding the risk and benefits of a radical surgery.

\section{Conflict of Interest}

The authors declare no conflicts of interests.

\section{Authors' Contributions}

All authors equal contributed to this paper.

\section{References}

1. Ferlay J, Soerjomataram I, Dikshit R, Eser S, Mathers C, Rebelo M, et al. Cancer incidence and mortality worldwide: sources, methods and major patterns in GLOBOCAN 2012. Int J Cancer. 2015; 136(5): E359-86.

2. Cunningham D, Allum WH, Stenning SP, Thompson JN, Van de Velde $\mathrm{CJ}$, Nicolson M, et al. Perioperative chemotherapy versus surgery alone for resectable gastroesophageal cancer. N Engl J Med. 2006; 355(1):11-20.

3. Bang YJ, Kim YW, Yang HK, Chung HC, Park YK, Lee KH, et al. Adjuvant capecitabine and oxaliplatin for gastric cancer after D2 gastrectomy (CLASSIC): a phase 3 open-label, randomised controlled trial. Lancet. 2012;379(9813):315-21.

4. Hundahl SA, Macdonald JS, Benedetti J, Fitzsimmons T, Southwest Oncology G, the Gastric I. Surgical treatment variation in a prospective, randomized trial of chemoradiotherapy in gastric cancer: the effect of undertreatment. Ann Surg Oncol. 2002;9(3):278-86.

5. Bonenkamp JJ, Hermans J, Sasako M, van de Velde CJ, Welvaart K, Songun I, et al. Extended lymph-node dissection for gastric cancer. N Engl J Med. 1999;340(12):908-14.

6. Hundahl SA, Wanebo HJ. Changing gastric cancer treatment in the United States and the pursuit of quality. Eur J Surg Oncol. 2005; 31(6):605-15.

7. Bartlett EK, Roses RE, Kelz RR, Drebin JA, Fraker DL, Karakousis GC. Morbidity and mortality after total gastrectomy for gastric malignancy using the American College of Surgeons National Surgical Quality Improvement Program database. Surgery. 2014;156(2):298-304.

8. Finlayson EV, Goodney PP, Birkmeyer JD. Hospital volume and operative mortality in cancer surgery: a national study. Arch Surg. 2003;138(7):721-5; discussion 6 .

9. Lee KG, Lee HJ, Yang JY, Oh SY, Bard S, Suh YS, et al. Risk factors associated with complication following gastrectomy for gastric cancer: retrospective analysis of prospectively collected data based on the Clavien-Dindo system. J Gastrointest Surg. 2014;18(7):1269-77.

10. Wu XS, Wu WG, Li ML, Yang JH, Ding QC, Zhang L, et al. Impact of being overweight on the surgical outcomes of patients with gastric cancer: a meta-analysis. World J Gastroenterol. 2013;19(28): 4596-606.

11. Hamakawa T, Kurokawa Y, Mikami J, Miyazaki $Y$, Takahashi T, Yamasaki M, et al. Risk factors for postoperative complications after gastrectomy in gastric cancer patients with comorbidities. Surg Today. 2016;46(2):224-8.

12. Dindo D, Demartines N, Clavien PA. Classification of surgical complications: a new proposal with evaluation in a cohort of 6336 patients and results of a survey. Ann Surg. 2004;240(2):205-13.

13. Gong DJ, Miao CF, Bao Q, Jiang M, Zhang LF, Tong XT, et al. Risk factors for operative morbidity and mortality in gastric cancer patients undergoing total gastrectomy. World J Gastroenterol. 2008; 14(42):6560-3.

14. Seo SH, Hur H, An CW, Yi X, Kim JY, Han SU, et al. Operative risk factors in gastric cancer surgery for elderly patients. J Gastric Cancer. 2011;11(2):116-21.

15. Jeong O, Park YK, Ryu SY, Kim YJ. Effect of age on surgical outcomes of extended gastrectomy with D2 lymph node dissection in gastric carcinoma: prospective cohort study. Ann Surg Oncol. 2010;17(6): 1589-96.

16. Kim W, Song KY, Lee HJ, Han SU, Hyung WJ, Cho GS. The impact of comorbidity on surgical outcomes in laparoscopy-assisted distal gastrectomy: a retrospective analysis of multicenter results. Ann Surg. 2008;248(5):793-9.

17. Orsenigo E, Bissolati M, Socci C, Chiari D, Muffatti F, Nifosi J, et al. Duodenal stump fistula after gastric surgery for malignancies: a retrospective analysis of risk factors in a single centre experience. Gastric Cancer. 2014;17(4):733-44.

18. Jeong SH, Ahn HS, Yoo MW, Cho JJ, Lee HJ, Kim HH, et al. Increased morbidity rates in patients with heart disease or chronic liver disease following radical gastric surgery. J Surg Oncol. 2010;101(3):200-4.

19. Mariette C, De Botton ML, Piessen G. Surgery in esophageal and gastric cancer patients: what is the role for nutrition support in your daily practice? Ann Surg Oncol. 2012;19(7):2128-34.

20. Wu MH, Lin MT, Chen WJ. Effect of perioperative parenteral nutritional support for gastric cancer patients undergoing gastrectomy. Hepatogastroenterology. 2008;55(82-83):799-802.

21. Hennessey DB, Burke JP, Ni-Dhonochu T, Shields C, Winter DC, Mealy K. Preoperative hypoalbuminemia is an independent risk factor for the development of surgical site infection following gastrointestinal surgery: a multi-institutional study. Ann Surg. 2010;252(2):325-9.

22. Cozzaglio L, Coladonato M, Biffi R, Coniglio A, Corso V, Dionigi P, et al. Duodenal fistula after elective gastrectomy for malignant disease : an italian retrospective multicenter study. J Gastrointest Surg. 2010; 14(5):805-11.

23. Liedman B, Andersson H, Berglund B, Bosaeus I, Hugosson I, Olbe L, et al. Food intake after gastrectomy for gastric carcinoma: the role of a gastric reservoir. Br J Surg. 1996;83(8):1138-43.

24. Qi J, Zhang P, Wang Y, Chen H, Li Y. Does Total Gastrectomy Provide Better Outcomes than Distal Subtotal Gastrectomy for Distal Gastric Cancer? A Systematic Review and Meta-Analysis. PLoS One. 2016;11(10):e0165179.

25. Sano T, Sasako M, Mizusawa J, Yamamoto S, Katai H, Yoshikawa T, et al. Randomized Controlled Trial to Evaluate Splenectomy in Total Gastrectomy for Proximal Gastric Carcinoma. Ann Surg. 2017; 265(2):277-83. 